\title{
REDUCTION OF ACEH'S INCOME INEQUALITY BY THE CONTRIBUTION OF THE FISHERIES, AGRICULTURE AND FORESTRY SECTORS
}

\author{
Agus Naufal'), Wiwiek Rindayati' ${ }^{2)}$ \\ ${ }^{1}$ Faculty of Fishery, Universitas Abulyatama \\ naufal.agus@abulyatam.ac.id \\ ${ }^{2}$ Faculty of Economics and Management, Institut Pertanian Bogor \\ wiwiekrinda@yahoo.com
}

\begin{abstract}
The aimed of this study is to determine the dynamics of income inequality in Aceh and the role of the fisheries, agriculture and forestry sector (FAF) in reducing income inequality in Aceh. The method used to find income inequality using the Williamson index, while to find the role of the FAF sector in reducing income inequality is to compare the Williamson index by including the FAF sector and without including the FAF sector. The results of the analysis show that there has been a dynamic of regional income inequality in Aceh which is decreasing. After the analysis, it is seen that income inequality will increase if the GDP of the FAF sector is excluded from the count. These results are reinforced by the results of the analysis of a strong negative correlation between GRDP of the FAF sector and the Inequality Index, which means that an increase in the contribution of the FAF sector will reduce the income inequality that occurs. The two-mean paired test also strengthens the evidence that the Inequality Index by including the FAF sector GRDP in the calculation is smaller than the Inequality Index without including the FAF sector GRDP.
\end{abstract}

Keywords: income inequality, williamsons index, gross regional domestic product, Aceh

\section{INTRODUCTION}

Indonesia has more than 490 ethnic group (Wanandi, 2002). Each region in Indonesia also has its own distinct characteristics including natural resources, economy, socio-culture, customs, number and density of population, quality of human resources, geographical location, as well as facilities and infrastructure available in each region (BPS, 1996).

These differences in characteristics affect the ability to grow of each region, thus making development in some regions grow faster than the development of other regions. This different ability to grow is also followed by differences in patterns of economic development which then lead to income inequality between regions. Indonesia's economic development is almost the same as in developing countries, generally only focusing on high economic growth without considering the allocation of income distribution in each region. Based on the calculation of the Williamsons Inequality Index which compares the amount of GRDP per capita between provinces in Indonesia in 2000-2007, the Williamsons Index of Indonesia ranges from 0.8455-0.8570 with an average of 0.8533 (Suparno, 2008).

Inequality cannot be eliminated, but can only be reduced to a level that can be accepted by a particular social system so that harmony within the system is maintained in its growth process (Supriyantoro, 2005). Therefore, inequality will always exist in poor countries, developing countries and developed countries. Each country can only suppress the value of inequality as low as possible. Inequality that is getting wider over time will lead to dissatisfaction which leads to conflict. The accumulation of such dissatisfaction can endanger the Unitary State of the Republic of Indonesia, because it is manifested in the movement of territorial separation or separatism. This illustrates that there is a high inequality between provinces in Indonesia, especially in terms of the unequal 
distribution of income per capita of the population. The high level of income inequality indicates uneven development in Indonesia, especially in the economic sector, so that inequality in Indonesia has become a serious problem. The highest contribution of this sector to the Aceh economy was in 2001 which amounted to 23.53 percent. Economic growth in this sector averaged only 1.52 percent annually, but was able to absorb 56.31 percent of the workforce in 2006 and 49.62 percent in 2007. This proves that the FAF sector is a sector that is very influential on the economy Aceh so that it can become a leading sector in Aceh (Naufal \& Rindayati, 2019).

Therefore, the FAF sector is needed, the sector which is the livelihood of the Acehnese people, most of whom belong to the lower middle class, is expected to reduce the problem of income inequality between regions in the Aceh Government. Based on this information, the purpose of this study are to determine the dynamics of income inequality in Aceh and the role of FAF sectors in reducing income inequality in Aceh.

\section{STUDY OF LITERATURE}

\section{Inequality}

According to Wie (1981), rapid economic growth in general accompanied by an increasingly unequal distribution of income. The only country only emphasizes economic growth, without taking into account the distribution of the country's income will lead to inequalities including: Income inequality between groups or relative inequality, Income inequality between groups is usually measured by using the Gini coefficient. Although the Gini coefficient is not ideal coefficient for measuring income inequality between various groups, but at least this number can provide an idea of general trends in income distribution patterns. Inequality between urban communities and rural communities, inequality in income distribution can also be viewed in terms of the difference in income between the village community and the community cities (urban-rural income disparities). To distinguish this, used the first two indicators compared between income levels in rural and urban areas. Second, regional income disparities rural and urban. Inequality of income distribution between regions, a study on the other side in see inequalities in national income are inequality in inter-regional economic growth in various regions in Indonesia, resulting in a pattern of income inequality between regions (regional income disparities). This income inequality is caused by unequal distribution of natural resources and at a rapid rate regional growth and the unsuccessful efforts of change evenly across regions in Indonesia.

Kuznets (1957) in Todaro (2003) said that in the early stages of economic growth, income distribution tends to deteriorate, but in the next stage the distribution of income will improve. This observation is what known as the "U hypothesis" or the "inverted-U" Kuznets curve, because longitudinal (time-series) changes in the income distribution. This hypothesis generated by empirical studies drawn from the growth patterns of a number of countries in the world, that in the early stages of economic growth occurstrade-off between growth and equity. Gradually in line with economic development growth after reaching a certain stage the inequality will disappear replaced with a correlation relationship positive relationship between equity and growth. This pattern arises because at the early stages of development tend to be more focused on the modern sector which absorb a little labor. The modern sector is growing fast leaving the traditional sector (agriculture). Gaps between sectors. This modern and traditional sector causes inequality. Income inequality tends to be high because most of the population are still low-income, and the modern sector has developed without changes in the production structure and appropriate allocation of labor for a modern economic growth as a whole. 


\section{METHODS}

\section{Data Types and Sources}

In analyzing the role of the FAF sector in reducing income inequality between regions in Aceh, there are several stages that must be carried out. These stages are an analysis of income inequality between regions in Aceh and an analysis of the role of the FAF sector in reducing income inequality in Aceh. This study analyzes secondary data from 2000 and 2007 using Microsoft office excel 2007 and Minitab software.

Secondary data needed includes: (1) sectoral GRDP of each regency / city in the Aceh area based on constant prices, (2) population by district /city, (3) Nangroe Aceh Darussalam province in numbers, and (4) various other secondary data. The sources were obtained from: (1) the Central Statistics Agency, (2) the Aceh Statistics Agency, (3) the Aceh FAF Service, and (4) from the publication of several previous research results.

\section{Income Inequality Analysis}

Measurement of income inequality between regions in Aceh province can be done using the Williamsons Index (CVw) method with the formula (Tambunan, 2003):

Where,

$$
C V w=\frac{\sqrt{\sum_{i}^{n}\left(\bar{Y}_{i}-\bar{Y}\right)^{2} \frac{f i}{n}}}{\bar{Y}}
$$

$\mathrm{CVw}$ : Williamson regional inequality index

Fi : Total population in the i-th area (people)

$\mathrm{N} \quad:$ Total population (people)

$\overline{\boldsymbol{Y}}_{\boldsymbol{i}} \quad:$ GRDP per capita at constant prices in the-i region (rupiah)

$\overline{\boldsymbol{Y}} \quad$ : GRDP per capita at constant prices for the province (rupiah)

\section{Analysis of the Role of the FAF Sector on Aceh's Income Inequality}

To see the role of the FAF sector on regional income inequality, it is done by calculating regional income inequality without including the FAF sector GRDP value in the calculation. Then compared with the level of inequality by entering the GRDP of the FAF sector. If after the FAF sector GRDP is excluded from the calculation, the inequality gets bigger, it means that the FAF sector plays a role in reducing the level of inequality that occurs.

To see the significance of the difference between the magnitude of the level of inequality by including the FAF sector GRDP (CVwp) and the magnitude of the inequality level without including the FAF sector GRDP (CVwnp) in the calculation, two paired middle values were tested.

The hypothesis:

Ho : $\mu_{\mathrm{D}}=\mathrm{d} 0$ (no difference between CVwnp and CVwp)

$\mathrm{H} 1: \mu_{\mathrm{D}}>\mathrm{d} 0(\mathrm{CVwnp}>\mathrm{CVwp})$

Where:

$\mu_{\mathrm{D}}: \mathrm{CVwnp}-\mathrm{CVwp}$ (Index of Inequality without including FAF sector minus Inequality Index of all sectors) $\mathrm{d}_{0}: 0$

The expected decision is to reject $\mathrm{H} 0$ which means the Inequality Index without including FAF sector GRDP (CVwnp) is greater than the Inequality Index entering FAF sector GRDP (CVwp) at the confidence level (1a) percent.

To see the linear relationship between the analyzed variables (per capita GRDP, FAF sector contribution, and Inequality Index) correlation coefficient is used. Walpole (1988) formulated correlation analysis with the formula: 
$-1 \leq \mathrm{r} \leq 1$

$$
r=\frac{n \sum x y-\left(\sum x\right)\left(\sum y\right)}{\sqrt{\left[n \sum x^{2}-\left(\sum x\right)^{2}\right]\left[n \sum y^{2}-\left(\sum y\right)^{2}\right]}}
$$

Where:

$\mathrm{r}=$ Correlation coefficient

$\mathrm{n}=$ Number of data (n-years)

To see the role of the FAF sector on inequality, a correlation analysis was carried out between the FAF sector's GRDP and the Inequality Index, where:

$\mathrm{x}=$ FAF sector GRDP (rupiah)

$\mathrm{y}=$ Inequality Index

The closer $r$ is to 1 or -1 , the stronger the correlation, both positive and negative. On the other hand, the closer to 0 , the weaker the correlation.

\section{RESULTS AND DISCUSSION}

\section{Results}

\section{Income Inequality Analysis}

The results of the calculation of income inequality in Aceh use only data from 21 of 23 districts/cities in Aceh. This is due to the Inequality Index value of all districts/cities in Aceh which reaches 1.67, while the Inequality Index value itself must be between 0 and 1 . North Aceh) which has a GRDP per capita reaching 4-6 times the other regions in Aceh was excluded from the calculation. The calculation results after the Williamson index calculation without including the city of Lhokseumawe and North Aceh district are presented in Table 1.

Table 1 Income Inequality Index in Aceh Government Regions 2000-2007 (Without Lhokseumawe and Aceh Utara)

\begin{tabular}{lll}
\hline No. & Year & CVw \\
\hline 1 & 2000 & 0.425624 \\
2 & 2001 & 0.446708 \\
3 & 2002 & 0.308981 \\
4 & 2003 & 0.322510 \\
5 & 2004 & 0.352863 \\
6 & 2005 & 0.330206 \\
7 & 2006 & 0.344955 \\
8 & 2007 & 0.204332 \\
\hline
\end{tabular}

\section{The Role of the Agricultural Sector in Reducing Inequality}

The results of the comparison of the calculation of the Inequality Index by including GRDP in the FAF sector and without including the FAF sector can be seen in Table 2. 
Table 2 The role of the FAF sector in reducing Income Inequality in Aceh 2000-2007 (Without Lhokseumaweand North Aceh)

\begin{tabular}{cccc}
\hline & \multicolumn{2}{c}{ CVw } & FAF Sector \\
\cline { 2 - 3 } Year & $\begin{array}{c}\text { With FAF } \\
\text { Sector }\end{array}$ & $\begin{array}{c}\text { Without } \\
\text { FAF } \\
\text { Sector }\end{array}$ & $\begin{array}{c}\text { GDRP } \\
\text { (million } \\
\text { rupiah) }\end{array}$ \\
\hline 2000 & 0.425624 & 0.693471 & 5637198 \\
2001 & 0.446708 & 0.761325 & 5929688 \\
2002 & 0.308981 & 0.593032 & 6840498 \\
2003 & 0.322510 & 0.606242 & 6363700 \\
2004 & 0.352863 & 0.610528 & 6742303 \\
2005 & 0.330206 & 0.641326 & 6393517 \\
2006 & 0.344955 & 0.650858 & 6487144 \\
2007 & 0.204332 & 0.533987 & 6843063 \\
\hline
\end{tabular}

Figure 1 shows a boxplot of the comparison of the two inequality indices using the Minitab application.

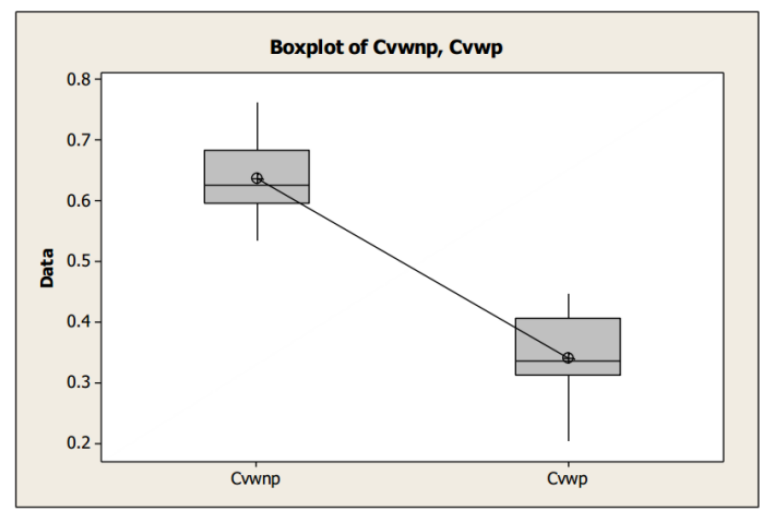

Figure 1 Boxplot Comparison between the Williamson Index andIncludes FAF Sector GRDP and Williamson Index Without Including FAF Sector GRDP

Table 3 presents data on the results of the Paired sample $t$ test between the Inequality Index by including GRDP in the FAF sector and without including the FAF sector.

Table 3 Results of Paired sample $t$ test between the Inequality Index by including GRDP in the FAF sector and without including the FAF sector

\begin{tabular}{cllll}
\hline & $\mathrm{N}$ & Mean & StDev & SE Mean \\
\hline CVw without & & & & \\
$\quad$ FAF & 8 & 0.636347 & 0.068707 & 0.024292 \\
CVw with & & & & \\
FAF & 8 & 0.342022 & 0.074302 & 0.026270 \\
Difference & 8 & 0.294324 & 0.024897 & 0.008802 \\
\hline
\end{tabular}

Table 4 presents the results of the correlation analysis between the FAF sector's GRDP and the Inequality Index. 
Table 4 The results of the correlation analysis of the relationship between FAF sector GRDP and the Inequality Index.

\begin{tabular}{lll}
\hline & CVw & GDRP \\
\hline CVw & 1.000 & -0.814 \\
GDRP & -0.814 & 1.000 \\
\hline
\end{tabular}

\section{Discussion}

Income Inequality Analysis The calculation of income inequality in this study uses a formula or formula introduced by Williamson (1965) which is often called CV Williamson (CVw). The greater the value, the greater the level of income inequality that occurs, and vice versa. After calculating without including the city of Lhokseumawe and the district of North Aceh, it turns out that there is a tendency for income inequality to decrease in the Aceh region in the period 2000-2007 (Table 1). This is indicated by the smaller number of Williamson Index obtained from the calculation results.

Income inequality in Aceh, which is relatively convergent, tends to decrease from year to year, but also fluctuates. In 2000 the level of inequality in Aceh was 0.425624 while in 2001 it reached the highest peak of inequality during the analysis period, which was 0.446708 . While in the following year it fell to 0.308981 . The lowest inequality during the analysis period occurred in 2007 with a Williamson index value of 0.204332. This is presumably due to a significant increase in the FAF sector in Aceh (Table 2). Likewise, in 2002, inequality decreased, presumably because the GRDP of the FAF sector increased with a fairly large increase.

\section{The Role of the FAF Sector in Reducing Aceh's Income Inequality}

In analyzing the role of the FAF sector on regional income inequality, it can be done by comparing the magnitude of the Williamson Index which includes GRDP from the FAF sector (all sectors) in the calculation with the magnitude of the Williamson Index without including GRDP from the FAF sector. The difference between the two indexes will reflect the role of the FAF sector in reducing income inequality in the Aceh region. From the calculation results in Table 2, it can be seen that the value of the Inequality Index by including the GRDP of the FAF sector in the calculation is smaller than the Inequality Index without including the GRDP of the FAF sector. In 2000-2007 the Inequality Index without GRDP in the FAF sector ranged from $0.693471602-0.533987351$. When the calculation is made by entering the GRDP of the FAF sector, the Inequality Index drops to around 0.425624060 - 0.204331984 . This shows that the FAF sector has been able to suppress or reduce income inequality during the analysis period (2000-2007).

In plain view, it can be seen that the value of the Inequality Index by including the GRDP of the FAF sector in the calculation is smaller than the Inequality Index without including the GRDP of the FAF sector (Table 2). After the Paired sample $t$ test was performed, it was proven to be significant at the 5 percent level of significance (Table 3). Figure 1. Shows that the value of the Inequality Index without including FAF sector GRDP in the calculation is greater than the Inequality Index which includes FAF sector GRDP. After careful observe, the development of these percentages in the analysis period shows that if the percentage of FAF is large, inequality will decrease, and vice versa if the percentage of FAF is small, inequality will increase. In Table 2, in 2007 inequality occurred at 0.204331984 (the smallest inequality during the analysis period), the GRDP of the FAF sector in that year was 6843 billion rupiah (the largest during the analysis period). This evidence further reinforces the fact that the FAF sector has a major role in reducing income inequality, particularly in Aceh.

The results of the correlation analysis also show that there is a negative correlation between the GDP of the FAF sector and the Inequality Index. The correlation between FAF sector GRDP and the Inequality Index is very strong at -0.814 (Table 4). It can be interpreted that the greater the contribution of the FAF sector, the smaller the level of income inequality, which means a more even distribution of income in Aceh. 


\section{CONCLUSIONS}

Based on the results of the analysis, it is known that there has been a dynamic of regional income inequality in the Government of Aceh which has decreased during the 2000-2007 analysis period. The highest inequality occurred in 2001 at 0.44 while the lowest inequality occurred in 2007 at 0.20 .

The FAF sector has a significant role in reducing income inequality in the Aceh Government area, and is also able to increase Aceh's economic growth. After the analysis, it is seen that income inequality will increase if the GDP of the FAF sector is excluded from the count. Based on the two-means paired test, it also strengthens the evidence that the Inequality Index by including the FAF sector GRDP in the calculation is smaller than the Inequality Index without including the FAF sector GRDP. Based on the results of the correlation analysis, it is also found that there is a strong negative relationship between GRDP in the FAF sector and the Inequality Index, meaning that an increase in the contribution of the FAF sector will reduce the income inequality that occurs. Another correlation analysis shows that there is a positive relationship between the percentage of FAF and GRDP per capita. This shows that areas dominated by the FAF sector tend to have high GRDP per capita compared to areas dominated by the non-FAF sector, thus the FAF sector is able to increase economic growth in Aceh.

The FAF sector has a significant role in reducing income inequality, which is expected to be given more attention in its improvement, and become a priority in development, in order to remain the leading sector in Aceh. The dynamics of decreasing inequality in Aceh are expected to be maintained. With the dynamics of inequality decreasing, prosperity in Aceh will be achieved.

\section{REFFERECES}

Badan Pusat Statistik. (1996). Statistik Indonesia. BPS. Jakarta

Naufal, A., \& Rindayati, W. (2019, December). Analysis of Fisheries, Agriculture and Forestry Sector Contributions to Aceh's Economic Growth. In Prosiding SEMDI-UNAYA (Seminar Nasional Multi Disiplin Ilmu UNAYA) (Vol. 3, No. 1, pp. 124-131).

Suparno. (2008). Analisis Pergeseran Struktur Ekonomi dan Penentuan Sektor Ekonomi Unggulan Kawasan Sulawesi. Departemen Ilmu Ekonomi, Fakultas Ekonomi dan Manajemen, Institut Pertanian Bogor, Bogor.

Supriyantoro. (2005). Analisis Ketimpangan Pendapatan Antar kabupaten/Kota di Provinsi Jawa Tengah. Departemen Ilmu Ekonomi, Fakultas Ekonomi dan Manajemen, Institut Pertanian Bogor, Bogor.

Tambunan, T. (2003). Perekonomian Indonesia : Beberapa Masalah Penting. Ghalia Indonesia. Jakarta.

Todaro, M. P. Smith, S. C. (2003). Pembangunan Ekonomi di Dunia Ketiga. Jilid ke-1. Edisi Ke-8. Munandar dan Puji [penerjemah]. Erlangga, Jakarta.

Walpole, R.E. (1988). Pengantar Statistika Edisi Ke-3. Bambang Sumantri [penerjemah]. Gramedia Pustaka Utama, Jakarta.

Wanandi, J. (2002). Indonesia: a failed state?. Washington Quarterly, 25(3), 135-146.

Wie, T.K. (1981). Pemerataan, Kemiskinan, Ketimpangan. Sinar Harapan, Jakarta. 